\title{
Use of analgesic and anti-inflammatory drugs before assistance in a children's first aid unit*
}

\author{
O uso de fármacos analgésicos e anti-inflamatórios prévio ao atendimento em pronto socorro \\ infantil
}

Camila Nogueira Prolungatti', Rita de Cássia da Silva Rodrigues Garcia ${ }^{1}$, Silvia Maira Pereira Cintra ${ }^{1}$, Rosemeire Isabel Ramos Análio ${ }^{1}$, Oscar César Pires ${ }^{1}$

${ }^{*}$ Received from University of Taubaté, Taubaté, SP, Brazil.

DOI $10.5935 / 1806-0013.20140028$

\section{ABSTRACT}

BACKGROUND AND OBJECTIVES: Drug administration to children is a widely spread practice, however it may lead to several health problems, because in addition to medical guidance it requires attention of parents and caregivers. This study aimed at identifying the prevalence of drug administration in children by their tutors, before medical assistance.

METHODS: This is a quantitative descriptive research involving adults who were escorting children, before medical assistance in a Children's First Aid Unit of a medium-sized city of the Vale do Paraiba Paulista in the months of June, July and August 2011, being data recorded by means of a specific form.

RESULTS: Participated in the study 105 adults responsible for the children who reported that $71.42 \%$ of children were medicated before medical assistance and only $28.58 \%$ have not adopted such practice. Most frequent symptom was fever, present in $40 \%$ of participants, and drugs used were paracetamol and dipirone.

CONCLUSION: Our results allow concluding that there has been a high rate of drug administration to children before medical assistance, with predominance of non-steroid antiinflammatory drugs, which may be noxious to health. It is clear the need for the adoption of measures which favor the access to health services, in addition to the awareness about the risk of administering drugs without medical prescription. Keywords: Analgesics, Anti-inflammatory drugs, Children, Self-medication.

1. University of Taubaté, Taubaté, SP, Brazil.

Submitted in July 03, 2013.

Accepted for publication in April 15, 2014.

Conflict of interests: none.

Correspondence to:

Oscar César Pires

Avenida Itália, 1551 - Rua 13, nº 821 - Jardim das Naçốes

12030-212 Taubaté, SP, Brasil.

E-mail: ocpires@uol.com.br

(c) Sociedade Brasileira para o Estudo da Dor

\section{RESUMO}

JUSTIFICATIVA E OBJETIVOS: A administração de fármacos na criança é uma prática amplamente difundida, porém pode levar a inúmeros prejuízos à saúde, pois além da orientação médica, exige atenção dos pais e cuidadores. $\mathrm{O}$ objetivo deste estudo foi identificar a prevalência da administração de fármacos na criança, por seus responsáveis, previamente ao atendimento médico.

MÉTODOS: Trata-se de uma pesquisa quantitativa descritiva, envolvendo adultos que acompanhavam as crianças antes do atendimento médico em um Pronto Socorro Infantil de um município de médio porte do Vale do Paraíba Paulista, nos meses de junho, julho e agosto de 2011, sendo os dados registrados por meio de um formulário específico. RESULTADOS: Participaram do estudo 105 adultos responsáveis pelas crianças que relataram que $71,42 \%$ das crianças foram medicadas previamente ao atendimento médico e apenas $28,58 \%$ não adotaram essa prática. O principal sintoma citado foi febre, presente em $40 \%$ dos participantes, e os fármacos mais utilizados foram o paracetamol e a dipirona.

CONCLUSÁO: Os resultados obtidos permitem concluir que houve um alto índice de administração de fármacos nas crianças previamente ao atendimento médico, com predomínio dos anti-inflamatórios não esteroides, fármacos esses que podem causar lesôes à saúde. Evidencia-se a necessidade de adoção de medidas que favoreçam o acesso aos serviços de saúde, além da conscientização sobre os riscos da administração de fármacos sem a devida prescrição médica. Descritores: Analgésicos, Anti-inflamatórios, Automedicação, Criança.

\section{INTRODUCTION}

The association of self-medication and fewer visits to physicians, as well as less expenses with drugs, favor the replacement of formal health assistance by this practice ${ }^{1}$.

The habit of self-medication may bring damages to patients' health, such as the appearance of undesirable effects, worsening and masking of diseases, pharmacological 
largely involved with such practice ${ }^{2}$.

Safe administration to children poses a series of problems which are not found when drugs are administered to adults, widely varying according to age, weight, body surface area, capacity of absorbing, metabolizing and excreting them. Different from adult drugs, there are few standardized pediatric dose ranges; for this reason, and with few exceptions, substances are prepared and packaged with mean values for adult doses ${ }^{3}$.

Drug consumption pattern in Brazil is strongly influenced by the lack of control throughout the distribution chain, since production to commercialization, leading to abusive and irrational use of over-the-counter products and even of those needing medical prescription. As a consequence, there is growth in the number of intoxication and poisoning cases, which suggests inadequacies in production, circulation or use of pharmaceutical products ${ }^{4}$.

Among different self-medication methods there are: acquiring without prescription, sharing with other family members or social cycle, using prescriptions leftovers, reusing old prescriptions and non-complying with professional prescription by prolonging or early interrupting it $^{1}$.

Since 1970, there has been increasing concern with the safety of some products or drugs potentially noxious for children, determining that they should be commercialized in adequate packages and with this the incidence of children poisoning is significantly decreasing. However, even with such advances, poisoning is still a significant health concern and most cases are seen in children below six years of age $^{3}$.

This study aimed at identifying the prevalence of drug administration to children, by their tutors, before medical assistance.

\section{METHODS}

This is a quantitative descriptive research. The study was carried out with tutors of children before they were assisted in a Children's First Aid Unit of a medium-sized city of the Vale do Paraiba Paulista and who accepted to participate.

Sample was collected before medical assistance as from interview carried out by researchers with tutors who were escorting children in the waiting room, and lasting 2 to 3 minutes each. Data were collected in June, July and August 2011. Data were recorded in a form with three groups of variables: child identification data, tutors data and data regarding the use of drugs for the child.

This study was approved by the Research Ethics Committee, University of Taubaté, under CEP/UNITAU n ${ }^{\circ}$ 096/2011.

\section{RESULTS}

Participated in the study 105 adults, tutors of children, who were escorting them and were interviewed before chil- dren were assisted by the Children's First Aid Unit.

To characterize children's age, the following age group criteria were used: neonate, infant, pre-school age and school age ${ }^{3}$.

Age groups of children participating in the study were: infants $51.42 \%$, pre-school age $24.76 \%$, school age $22.85 \%$ and neonates $0.97 \%$. As to gender, $50.48 \%$ were females and $49.52 \%$ were males.

With regard to previous diseases, tutors have reported that $81.90 \%$ had no disease and $18.10 \%$ had diseases, being them: renal, Down syndrome, bronchitis, asthma, convulsive crisis, laryngitis.

When asked whether the child had already presented some type of pharmacological allergic reaction, $80.95 \%$ of tutors have said no, $15.24 \%$ had said that there had been already some allergic reaction and $3.81 \%$ could not answer. As to the regular presence of children in medical visits, $70.47 \%$ of tutors have said yes, $25.72 \%$ have said no and $3.81 \%$ could not answer. Regarding tutor taking children to the children's first aid unit, $69.52 \%$ were taken by the mother, $23.81 \%$ by others, among them grandmother, aunt, godmother and neighbor, and $6.67 \%$ by the father.

With regard to using drugs before medical assistance, it was found that $71.42 \%$ have medicated them and $28.58 \%$ have not medicated them previously.

With regard to continuous use of some drug by the child, their escorts have reported that $84.76 \%$ do not use and $15.24 \%$ use, being major drugs mentioned valproate, dexchlorpheniramine, vitamin $\mathrm{D}$, flunazirine and ferrous sulfate.

As to the reason why looking for Children's First Aid Unit assistance, most prevalent symptoms were fever, productive cough, vomiting, diarrhea, abdominal pain, sore throat, dyspnea and earache.

With regard to duration of signs and symptoms taking children to assistance, $80.95 \%$ of them had symptoms for 1 to 3 days, $11.43 \%$ for 4 to 6 days, $3.81 \%$ for 7 to 9 days, and $3.81 \%$ had symptoms for a period of 13 to 15 days. As to who has indicated the drug, in $78.67 \%$ it was the mother, in $13.33 \%$ the neighbor and in $8 \%$ the grandmother.

Among tutors medicating children before medical assistance, $55.23 \%$ have referred that the bottle of the administered drug was already open and, from these, $32.38 \%$ have referred checking its validity date.

Figure 1 shown drugs administered to children before Children's First Aid Unit assistance, according to reports of their escorts, pointing out that more than one drug has been administered to some children before looking for medical assistance.

As to the period using drugs before Children's First Aid Unit assistance, data are shown in figure 2.

Figure 3 shows the place where the drug administered before Children's First Aid Unit assistance was acquired. 


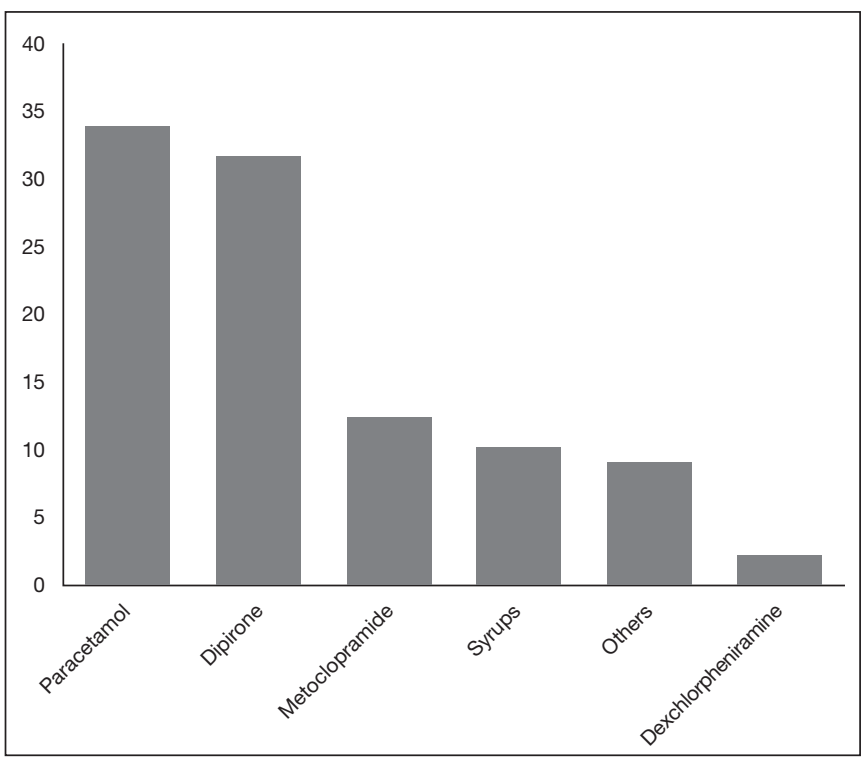

Figure 1. Drugs administered before medical assistance. Taubaté, 2011

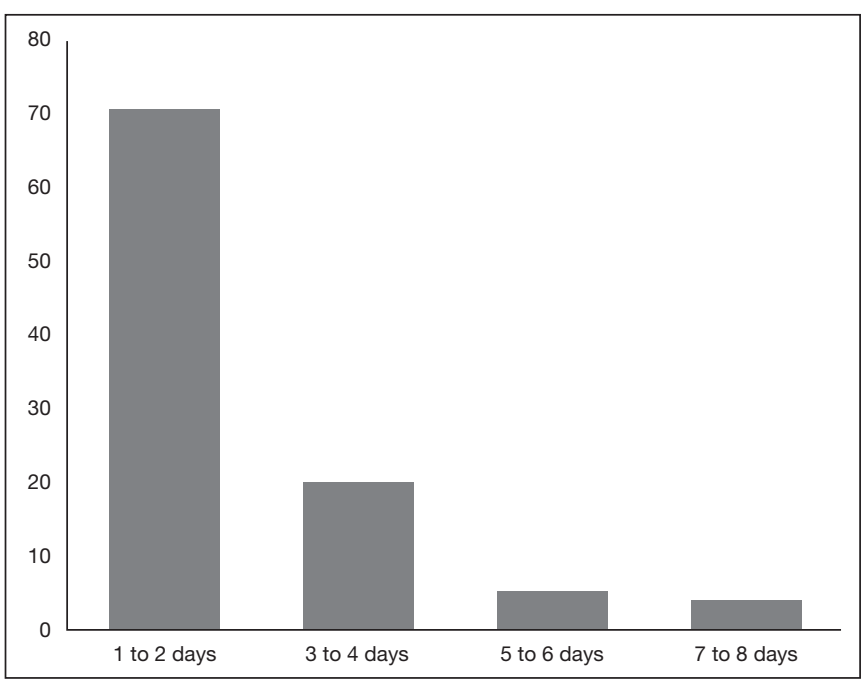

Figure 2. Period using drugs administered by tutors in home care before medical assistance. Taubaté, 2011

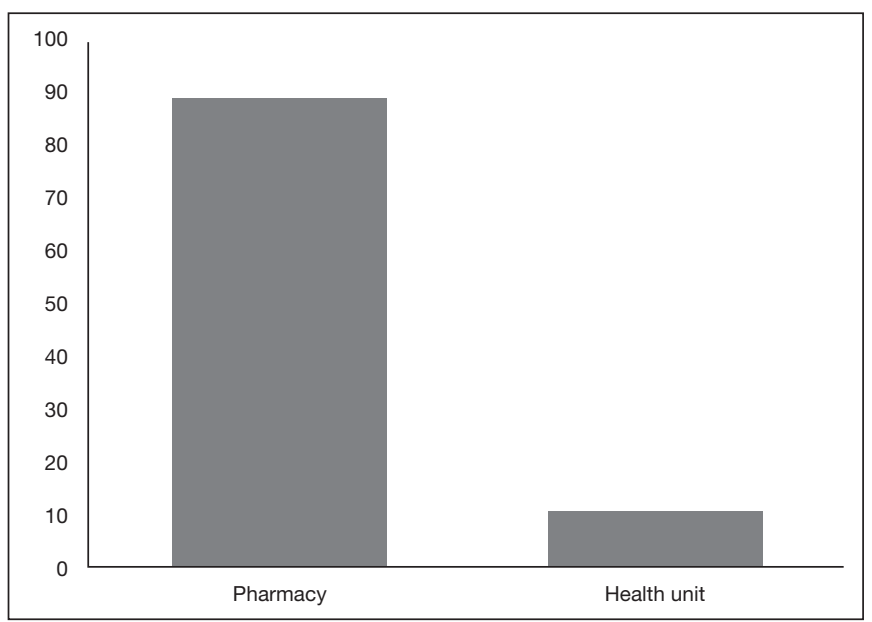

Figure 3. Places where the drug was acquired. Taubaté, 2011

\section{DISCUSSION}

A study on the use of drugs in children up to six years of age and enrolled in childcare units has found as most frequent diseases: bronchitis, rhinitis, allergy, sinusitis and asthma, among others, data which coincide with our results where prevalence of respiratory diseases was found 5 .

With regard to the reason why looking for assistance, most prevalent symptoms are similar to those presented by Carvalho et al. ${ }^{5}$ and Pereira et al. ${ }^{6}$.

Although fever is one of the most common complaints during pediatric assistance, being the first manifestation of acute viral infections, its presence is feared because it may be early sign of severe disease ${ }^{7}$.

According to figure 1, analgesics and antipyretics have been also mentioned by other authors as the most popular drugs for children's self-medication ${ }^{5,6,8}$.

Although drugs like paracetamol and dipirone are relatively safe analgesics and antipyretics for children, provided adequate doses are respected, chronic and abusive use of these medications should be avoided, since there are reports of liver toxicity with paracetamol and decreased blood defense cells with dipirone?

Figure 2 shows that $53(70.66 \%)$ drugs were administered for a period of 1 to 2 days, suggesting that children have not improved signs and symptoms.

Study on children's self-medication has found that mothers were largely responsible for indicating the drug, and this was consequence of previous use of such drugs under medical prescription ${ }^{6}$. Approach found in this study, and deserving special attention, was the use of drug bottles which had been opened in other moments, since after being opened, conservation conditions may alter the efficacy.

A study by Beckhauser et al. ${ }^{10}$ has found the pharmacy as the place where drugs for self-medication were largely acquired, similar result to our study and confirming the hypothesis that it is more practical to acquire a drug in a pharmacy than scheduling medical visits for the same purpose, however with greater risks.

\section{CONCLUSION}

Our results show high prevalence of children's self-medication, being analgesics and anti-inflammatory drugs the most widely used by mothers, suggesting the need for actions of collective health services to provide access and guidance to the population with regard to the risks of indiscriminate use without medical prescription.

\section{REFERENCES}

1. Loyola Filho AI, Uchoa E, Guerra HL, Firmo JO, Lima-Costa MF. [Prevalence and factors associated with self-medication: the Babuí health survey]. Rev Saúde Pública 2002;36(1):55-62. Portuguese.

2. Piotto FR, Nogueira RM, Pires OC, Cusma-Pelógia N, Posso IP. Prevalência da dor e do uso de analgésicos e anti-inflamatórios na automedicaçăo de pacientes atendidos no Pronto-Socorro Municipal de Taubaté. Rev Dor. 2009;10(4):313-7.

3. Hockenberry MJ. Fundamentos de Enfermagem Pediátrica. $7^{\text {a }}$ ed. Rio de Janeiro: Elsevier Ltda; 2006. 450-3,742-7,762-3p. 
4. Matos GC, Rozenfeld S, Bortoletto ME. Intoxicaçôes medicamentosas em crianças menores de cinco anos. Rev Saúde Matern Infant. 2002;2(2):167-76.

5. Carvalho DC, Trevisol FS, Menegali BT, Trevisol DJ. Uso de medicamentos em criança de zero a seis anos matriculadas em creches de Tubarão, Santa Catarina. Rev Paul Pediatr. 2008;26(3):238-44.

6. Pereira FS, Bucaretchi F, Stephan C, Cordeiro R. Self-medication in children and adolescents. J Pediatr. 2007;83(5):453-8.

7. Brook I. Unexplained fever in young children: how to manage severe bacterial infec- tions. BMJ. 2003;327(7423):1094-7.

8. Leite SN, Cordeiro BC, Thiesen D, Bianchini JP. Utilização de medicamentos e outras terapias antes de consulta pediátrica por usuários de unidade pública de saúde em Itajaí-SC, Brasil. Acta Farm Bonaerense. 2006;25(4):608-12.

9. Bricks LF. Uso judicioso de medicamentos em crianças. J Pediatr. 2003;79(1):107-14.

10. Beckhauser GB, Souza JM, Valgas C, Piovezan AP, Gala D. Utilizaçăo de medicamentos na Pediatria: a prática de automedicaçáo em crianças por seus responsáveis. Rev Paul Pediatr. 2010;28(3):262-8. 